\title{
EXPERIMENTS WITH POTATOES ON THE EFFECT OF THE PIGMENT-RESTRICTING GENE, $M$
}

\author{
H. W. HOWARD \\ Plant Breeding Institute, Trumpington, Cambridge
}

Received 5.viii.6t

\section{INTRODUCTION}

IT was found by Asseyeva (1931) that, when eyes were removed from white-splashed-pigment tubers of potato varieties and also of seedlings so that adventitious bud formation took place, some of the plants which developed from the adventitious buds produced white tubers. Asseyeva was using the eye-excision method to investigate suspected periclinal chimeras, but she realised that the production of the white tubers from plants which usually have white-splashed-pigment tubers was not connected with any chimerical constitution, as normally understood, of the parent tubers. Asseyeva's results have been confirmed (Howard, I958, I959 $a$ and $b$ ).

Howard (1959a and $b$ ) has suggested that the white tubers are the result of some process of differentiation in the parent tuber which results in the cells of the inner tissues not having the ability to produce anthocyanin pigments. When these inner cells are made by eyeexcision to dedifferentiate to form meristematic cells from which otherwise normal epidermal and later peridermal cells are produced, the ability to form anthocyanin pigments is not acquired and hence white tubers are found.

The experiments described in the present paper were carried out to obtain further knowledge of where the suggested differentiation of cells for ability and non-ability to produce pigmented periderm takes place. They indicate that it can be close to the growing point and not only in the inner tissues as previously suggested. They also show that it is connected with the action of the pigment-restricting gene, $M$, and that it does not occur when eyes are excised from tubers with full pink periderm.

\section{MATERIAL}

The seven clones used in the experiments were :

(a) Clones with white-splashed-pigment tubers

I. $\mathrm{Y}_{30} / 8$, white-splashed-purple, from the cross normal Red King $\times \mathrm{Cl}_{6} 6_{50}$ (white tubers).

2 and 3 . $\mathrm{V}_{27} \mathrm{~A}$ and $\mathrm{V}_{27} \mathrm{~B}$, both white-splashed-purple, from the cross $\mathrm{Y}_{30} / 8 \times$ Ulster Knight (white tubers).

(b) Periclinal chimera of full pink/white-splashed-pink 4. normal Red King (see Howard, I958 and 1959b).

(c) Clones with full-pigment tubers

5. Full pink Red King, obtained by X-ray treatment of normal Red King (see Howard, 1958 and $1959 b$ ). 
6. $\mathrm{T}_{39 / \mathrm{I}}$, full pink, from the cross of full pink Red King $\times$ Ulster Knight (white tubers).

7. WioB, full purple, from the cross $\mathrm{Y}_{30} / 8 \times$ Ulster Knight (white tubers).

Thus all seven clones are either Red King or bred from it. Red King itself arose as a bud sport in the variety King Edward VII (white, splashed pink, tubers), and it is a periclinal chimera in which only layer $I$ at the growing point has changed, layer II being still King Edward. Hence Red King produces hybrid progenies containing white-splashed-pigment, and not full pigment, types. The factor for white-splashed-pink in King Edward appears to be two closely linked genes, $E$ for pink pigment production in the periderm and $M$ which restricts the pigmentation to areas mainly around the eyes at the rose (apical) end (Howard, 1959b). EM only produces white-splashed-pink when the basic gene, $D$, for anthocyanin formation is also present. Red King may be, therefore, the result of somatic crossingover between the two genes, $E$ and $M$. Similarly the full colour of WroB is presumably due to a meiotic crossing-over. The purple, as opposed to pink, colour of $\mathrm{Y}_{30} / 8, \mathrm{~V}_{27} \mathrm{~A}, \mathrm{~V}_{27} \mathrm{~B}$ and $\mathrm{W}_{10 \mathrm{~B}}$ is caused by the gene $P$ which converts pink into purple (clone Cl.65o has purple sprouts). The tuber colour types are shown diagrammatically in fig. $\mathrm{I}$.

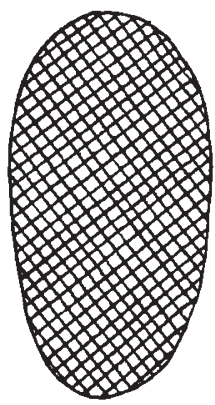

a

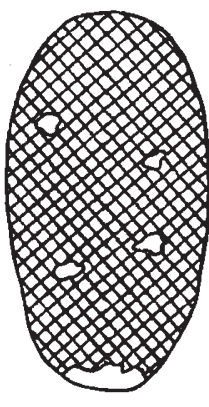

b
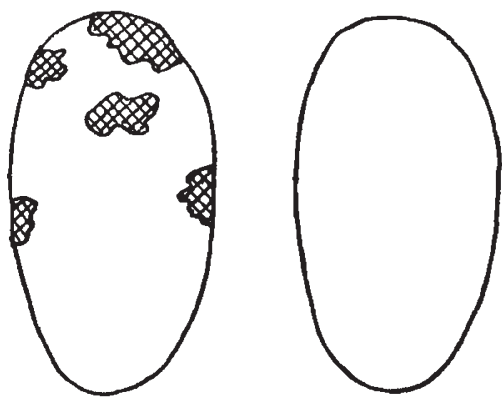

Fig. 1.-Tuber phenotypes (areas of pigmented periderm cross-hatched).

(a) Full pigment (full pink Red King, $\mathrm{T}_{39} / \mathrm{r}$ and $\mathrm{W}_{\mathrm{roB}}$ ).

(b) Normal Red King (periclinal chimera)-note small white patches which are areas of periderm produced from cambia formed in the outer cortex which traces back to layer II at the growing point. Most of the periderm is produced by cambia formed by the epidermal cells which are derived from layer I at the growing point. (c) White-splashed-pigment $\left(\mathrm{Y}_{30} \mathrm{O} / 8, \mathrm{~V}_{27} \mathrm{~A}\right.$ and $\left.\mathrm{V}_{27} \mathrm{~B}\right)$.

(d) White.

\section{EYE-EXCISION EXPERIMENTS}

An examination about a month after the planting of half tubers, from which the eyes have been removed, showed that callus outgrowths occur in two regions. First they may be found in large numbers over the vascular system on the flat cut surface made when the tuber was bisected, and secondly they occur occasionally in the places where eyes have been removed. Examination at a later date suggested that more adventitious buds are formed from the occasional calluses in the eye regions than from the more numerous calluses over the vascular system. It was also obvious that no callus outgrowths are produced by the periderm. All adventitious buds originate from cells of either the cortex or vascular bundles, and thus trace back 
TABLE I

(a) Control Series

Results for $\Upsilon_{30} / 8$

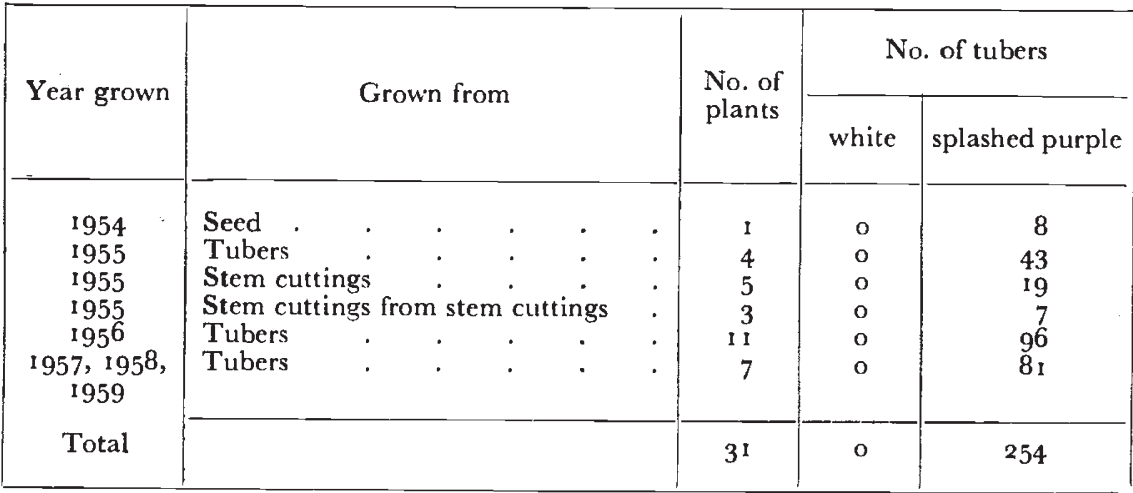

(b) Eye-excision experiments

\begin{tabular}{|c|c|c|}
\hline Year & $\begin{array}{l}\text { No. of eye-excised } \\
\text { tubers producing } \\
\text { plants }\end{array}$ & Types of tubers produced * \\
\hline $\begin{array}{l}1955 \\
1956 \\
1959 \\
1960\end{array}$ & $\begin{array}{l}3 \\
4 \\
2 \\
3\end{array}$ & $\begin{array}{l}6 \text { wh. : } 12 \text { spl. P. ; } 16 \text { wh. } \\
4 \text { spl. P. } 3 \text { wh. }+6 \text { spl. P. } 4 \text { wh. }+2 \text { spl. P. ; } 7 \text { wh. } \\
7 \text { wh. ; 10 wh. }+2 \text { spl. P. } \\
4 \text { wh. ; } 7 \text { wh. ; } 6 \text { wh. }\end{array}$ \\
\hline
\end{tabular}

* 4 spl. P. ; 3 wh. +6 spl. P. means that one plant produced 4 splashed purple tubers and another plant 3 white plus 6 splashed purple tubers.

(c) White tuber line from white tubers produced in the 1955 eye-excision experiment

\begin{tabular}{|c|c|c|c|}
\hline Year & $\begin{array}{c}\text { No. of plants } \\
\text { grown }\end{array}$ & \multicolumn{2}{|c|}{ No. of tubers } \\
\cline { 2 - 4 } & white & splashed purple \\
\hline 1956 & - & 79 & $(1)$ \\
1957 & 9 & 0 \\
1957 * & 9 & 0 \\
1958 and 1959 & 15 & 0 \\
Total . & 23 & 223 & (1) \\
\hline
\end{tabular}

* Plant from the 1956 tuber showing a very small purple splash.

(d) Comparison of hybrid progenies from white-splashed-purple and white $Y_{30} / 8$. The same male parent, Ulster Knight, which has white tubers and pink sprouts, was used for all three crosses

\begin{tabular}{|c|c|c|c|c|c|}
\hline \multirow{2}{*}{$\begin{array}{c}\text { Family } \\
\text { no. }\end{array}$} & \multirow{2}{*}{ Female parent } & \multicolumn{4}{|c|}{ No. of seedlings with tubers } \\
\hline & & white & splashed pink & splashed purple & full purple \\
\hline \multirow[t]{2}{*}{$\begin{array}{l}\text { W10 } \\
V_{27}(a) \\
V_{27}(b)\end{array}$} & \multirow[t]{2}{*}{$\begin{array}{l}Y_{30} / 8 \text { (splashed purple) } \\
Y_{30 / 8} \text { (splashed purple) } \\
Y_{30 / 8} \text { (white) }\end{array}$} & $\begin{array}{r}171 \\
228 \\
76\end{array}$ & $\begin{array}{l}74 \\
78 \\
28\end{array}$ & $\begin{array}{l}73 \\
89 \\
15\end{array}$ & $\begin{array}{l}1 \\
1 \\
1\end{array}$ \\
\hline & & 475 & 180 & 177 & 3 \\
\hline
\end{tabular}

Heterogeneity $\chi^{2}$ for white : total with colour, $3.52 ; n=2, \mathrm{P}=0 \cdot 10-0 \cdot 20$. 
respectively to layer II or layer III at the growing point. This is, of course, the reason why, after eye-excision, the tubers of monochlamydius chimeras, i.e. chimeras with a mutation in layer I only, produce plants with tubers of the same type as the original variety.

\section{(i) Results for $Y 30 / 8$ (white-splashed-purple tubers)}

The seedling $\mathrm{Y}_{30} / 8$ was chosen for the experiments because the purple splashes on its tubers were very well marked and because, therefore, the possibility of wrong scoring in its clonal progeny would be very small. This has been found to be so (table $\mathrm{r} a$ ), not a single white tuber being found in the control series.

Eye-excision leads to some plants producing either white tubers or a mixture of white and white-splashed-purple tubers (table $\mathrm{r} b$ ). Growing on from the white tubers produces plants which also have white tubers and only one tuber with a single, very small, purple patch was found. The plant from this tuber produced 15 white and no splashed-purple tubers in the following year (table $I c$ ). The change from white-splashed-purple to white, induced by eye-excision, thus appears to be permanent for $\mathrm{Y}_{30} \mathrm{O} / 8$ in vegetative reproduction.

When a plant from the white tuber line was crossed with Ulster Knight it was found that it gave a hybrid progeny similar to that of plants of th c control line (table $\mathrm{I} d$ ). It thus appears that the nuclei of cells of the white tubers still have the genes for production of splashed-pigment periderm.

The segregation in the families from $\mathrm{Y}_{30} / 8 \times$ Ulster Knight is a good fit to a ratio of I I pigmented : 13 white, $\mathrm{Y}_{30} / 8$ being probably duplex for the basic gene $D$ and simplex for $E M$ and Ulster Knight being simplex for $D$ and nulliplex for $E M$ (Howard, 1959b, table 3). Only a heterogeneity $\chi^{2}$ has been calculated for the data as segregations in potatoes are disturbed by the effects of double reduction and the functioning of aneuploid gametes (Catcheside, 1959). The purple : pink segregation is a perfect fit to $I: I$. The three plants with full purple periderm are presumably due to cross-overs between $E$ and $M$.

\section{(ii) Results for V27A and V27B (white-splashed-purple tubers)}

Less extensive results, but similar to those found for their parent ( $\mathrm{Y}_{30} / 8$ ), have been obtained for seedlings $\mathrm{V}_{27} \mathrm{~A}$ and $\mathrm{V}_{27} \mathrm{~B}$ (table 2). Plants from white tubers obtained as a result of eye-excision again gave plants which had white tubers. In the clonal progeny of a white tuber from $\mathrm{V}_{27} \mathrm{~B}$ a single sectorial chimera (fig. 2) was, however, found. Plants were grown from three single sprouts taken from this tuber, and also from the tuber itself, which was divided into three parts as shown in fig. 2a. The results (table 3) suggest that during the growth of the tuber about half the apical cells of layer I at the growing point had regained the ability to produce splashed purple.

Crosses of plants grown from the white tubers of $\mathrm{V}_{27} \mathrm{~A}$ and $\mathrm{V}_{27} \mathrm{~B}$ show, as was found for $\mathrm{Y}_{30} / 8$, that the nuclei of the cells of these 
TABLE 2

Results of eye-excision experiments

\begin{tabular}{|c|c|c|c|c|c|}
\hline \multirow{2}{*}{ Material } & \multirow{2}{*}{$\begin{array}{l}\text { No. of eye- } \\
\text { excised tubers } \\
\text { producing plants }\end{array}$} & \multicolumn{4}{|c|}{$\begin{array}{l}\text { No. of tubers from plants of } \\
\text { eye-excised tubers }\end{array}$} \\
\hline & & $\begin{array}{l}\text { full } \\
\text { colour }\end{array}$ & $\begin{array}{l}\text { normal } \\
\text { Red King }\end{array}$ & $\begin{array}{l}\text { splashed } \\
\text { pigment }\end{array}$ & white \\
\hline $\mathrm{Y}_{30} / 8$ (splashed purple) & 12 & $\ldots$ & $\ldots$ & 26 & 56 \\
\hline V27A (splashed purple). & 3 & $\ldots$ & $\ldots$ & 4 & 6 \\
\hline $\mathrm{V}_{27} \mathrm{~B}$ (splashed purple). & 2 & $\ldots$ & $\ldots$ & 0 & 9 \\
\hline Normal Red King . & 7 & $\ldots$ & o & 32 & 39 \\
\hline Full pink Red King & 3 & $2 \mathrm{I}$ & o & 0 & 0 \\
\hline 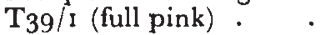 & 3 & 42 & $\ldots$ & $\ldots$ & o \\
\hline WIoB (full purple) & 2 & 26 & $\cdots$ & ... & 0 \\
\hline
\end{tabular}
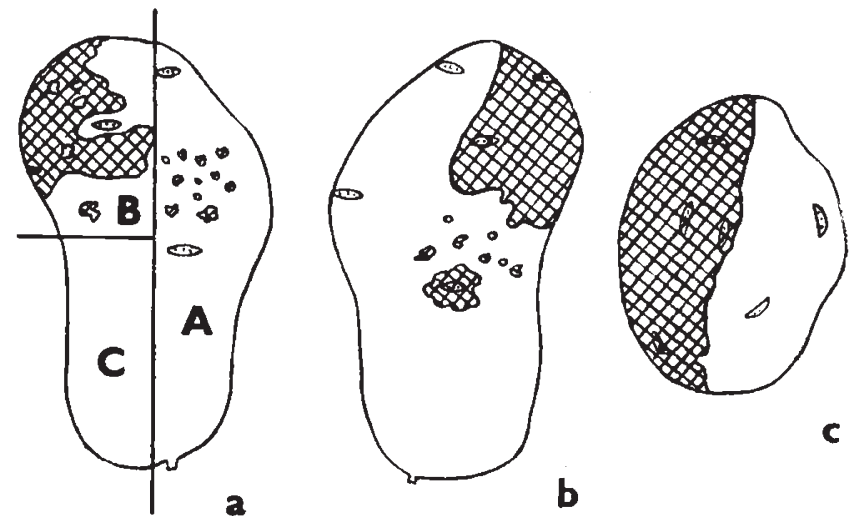

b

Fig. 2.-Sectorial chimerical tuber from $\mathrm{V}_{27} \mathrm{~B}$ white series. (Areas of pigmented periderm cross-hatched.) $\mathrm{A}, \mathrm{B}$ and $\mathrm{C}$ are the parts into which the tuber was divided for growing on, see table $3 . \quad(a)$ and $(b)$ side views, $(c)$ view of rose (apical) end.

TABLE 3

Progeny by vegetative reproduction from $V_{27} B$ sectorial chimerical tuber (see fig. 2)

\begin{tabular}{|c|c|c|}
\hline Part planted & & Tubers produced \\
\hline $\begin{array}{l}\text { White half }(\mathrm{A}) \\
\text { Splashed-purple rose end (B) } \\
\text { Heel end beneath B (C) } \\
\text { Sprout from white half (A) } \\
\text { Sprout from A/B border } \\
\text { Sprout from A/B border }\end{array}$ & : & $\begin{array}{l}\text { I } 5 \text { white } \\
\text { I I splashed purple } \\
\text { I } 5 \text { white }+2 \text { splashed purple } \\
\text { I } 5 \text { white } \\
\text { I } 8 \text { splashed purple } \\
8 \text { white+ I splashed purple }\end{array}$ \\
\hline
\end{tabular}

K 2 
tubers still possess the genes for splashed-pigment periderm. All three segregations are very good fits to I : I ratios for white : splashedpigment (table 4). This is probably due to $\mathrm{V}_{27} \mathrm{~A}$ and $\mathrm{V}_{27} \mathrm{~B}$ being triplex for $D$ and simplex for $E M$.

\section{TABLE 4}

Comparison of hybrid progenies from $V_{27} A$ (white from eye-excision), $V_{27} B$ (splashed purple) and $V_{27} B$ (white from eye-excision). The male parent for all three crosses was Ulster Knight which has white tubers and pink sprouts

\begin{tabular}{|c|c|c|c|c|c|}
\hline \multirow{2}{*}{$\begin{array}{c}\text { Family } \\
\text { no. }\end{array}$} & \multirow{2}{*}{ Female parent } & \multicolumn{4}{|c|}{ No. of seedlings with tubers } \\
\hline & & white & $\begin{array}{l}\text { splashed } \\
\text { purple }\end{array}$ & $\begin{array}{l}\text { splashed } \\
\text { pink }\end{array}$ & $\begin{array}{l}\text { full } \\
\text { pink }\end{array}$ \\
\hline Q55 & V27A (white) & 21 & 10 & 10 & 0 \\
\hline$Q_{56}$ & $\mathrm{~V}_{27} \mathrm{~B}$ (splashed purple) & 68 & 37 & $3^{2}$ & $\mathbf{i}$ \\
\hline$Q_{57}$ & $\mathrm{~V}_{27} \mathrm{~B}$ (white) & I 2 & 6 & 8 & 0 \\
\hline
\end{tabular}

(iii) Results from normal Red King

Eye-excision of normal Red King tubers produces plants which have either King Edward type (white-splashed-pink) or white tubers (table 2). This is as expected because normal Red King is a monochlamydius periclinal chimera and because the adventitious buds are formed from the inner tissues which are unchanged King Edward. Clonal progenies from the white tubers produce some plants with white tubers, but also plants with white-splashed-pink tubers (Howard, $1959 b$, table $2 b$ ). This result may be due to misclassification of tubers on the plants from the eye-excision experiments. Grown in pots in the glasshouse King Edward itself has many tubers with either few or no coloured splashes (see also section 5).

(iv) Results from full pink Red King, T39/1 and W1OB

Eye-excision of tubers of full pink Red King, of $\mathrm{T}_{39} / \mathrm{r}$ (full pink) and WıOB (full purple) produces plants which themselves have tubers with fully pigmented tubers and no white tubers have been found (table 2). It thus seems that the production of white tubers in eyeexcision experiments only occurs from white-splashed-pigment tubers and must be connected with the action of the pigment-restricting gene, $M$.

\section{X-RAY TREATMENT}

When X-rays were used to produce full pink Red King from normal Red King (Howard, I958), it was found that some plants produced white tubers. The frequency of these white tubers appeared to be 
much too high for them to be the result of induced mutations, and it seemed probable that their origin must be due to some process similar to that producing white tubers in eye-excision experiments. This hypothesis is supported by the results obtained from $\mathrm{X}$-ray treatment of $Y_{30} / 8$ (table 5 ).

TABLE 5

Results of $X$-ray experiments ( $3000 \mathrm{r}$ to rose ends of tubers with sprouts about $3 \mathrm{~mm}$. long)

\begin{tabular}{|c|c|c|c|c|c|}
\hline \multirow{2}{*}{ Material } & \multirow{2}{*}{$\begin{array}{l}\text { No. of } \\
\text { plants }\end{array}$} & \multicolumn{4}{|c|}{$\begin{array}{l}\text { Total tubers produced by plants from } \\
\text { treated rose-ends }\end{array}$} \\
\hline & & $\begin{array}{l}\text { full } \\
\text { colour }\end{array}$ & $\begin{array}{c}\text { normal } \\
\text { Red King }\end{array}$ & $\begin{array}{l}\text { splashed } \\
\text { pigment }\end{array}$ & white \\
\hline $\mathrm{Y}_{30} / 8$ (splashed purple) & I 2 & $\ldots$ & $\ldots$ & $36 *$ & II \\
\hline $\mathrm{Y}_{30 / 8}$ (white) & 5 & $\ldots$ & $\ldots$ & 2 & 50 \\
\hline Normal Red King . & Io & 4 & 54 & 20 & 12 \\
\hline Full pink Red King . & 18 & 123 & 0 & 0 & 0 \\
\hline $\mathrm{T}_{39 / \mathrm{I}}$ (full pink) . & 5 & 81 & $\ldots$ & $\ldots$ & 0 \\
\hline WioB (full purple) & 16 & $97 \dagger$ & $\ldots$ & $\ldots$ & 0 \\
\hline
\end{tabular}

* Includes one splashed pink mutant tuber (see also table 6).

† Includes 3 full pink mutant tubers.

Growing on the white tubers of $\mathrm{Y}_{30} / 8$ from the X-ray experiment has shown that they produce plants which have mostly white tubers. Six plants were grown. Four produced only white tubers (a total of $4^{\text {I }}$ tubers), but two had a mixture of white and white-splashedpurple ( 17 white and 8 splashed). Breeding from two of the plants,

TABLE 6

Comparison of hybrid progenies from normal white-splashed-purple, white from $X$-ray treatment, and white-splashed-pink $\Upsilon_{30} / 8$ from $X$-ray treatment. The same male parent, Ulster Knight (white tubers, pink sprouts) was used for all five crosses

\begin{tabular}{|c|c|c|c|c|c|c|}
\hline \multirow{2}{*}{$\begin{array}{c}\text { Family } \\
\text { no. }\end{array}$} & \multirow{2}{*}{ Female parent } & \multicolumn{5}{|c|}{ No. of seedlings with tubers } \\
\hline & & white & $\begin{array}{l}\text { splashed } \\
\text { purple }\end{array}$ & $\begin{array}{l}\text { full } \\
\text { purple }\end{array}$ & $\begin{array}{l}\text { splashed } \\
\text { pink }\end{array}$ & $\begin{array}{l}\text { full } \\
\text { pink }\end{array}$ \\
\hline $\begin{array}{l}\text { W10 } \\
\text { V.7 }_{27}(a) \\
Q_{59} \\
Q_{60}^{60} \\
Q_{58}^{8}\end{array}$ & 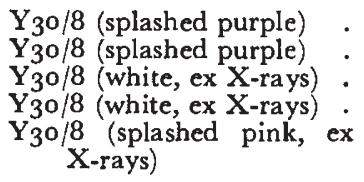 & $\begin{array}{r}171 \\
228 \\
165 \\
60 \\
73\end{array}$ & $\begin{array}{r}73 \\
89 \\
65 \\
23 \\
0\end{array}$ & $\begin{array}{l}\text { I } \\
\text { I } \\
0 \\
\text { I } \\
0\end{array}$ & $\begin{array}{l}74 \\
78 \\
59 \\
16 \\
54\end{array}$ & $\begin{array}{l}0 \\
0 \\
0 \\
0 \\
1\end{array}$ \\
\hline
\end{tabular}

Heterogeneity $\chi^{2}$ for families $W_{10}, V_{27} a, Q_{59}$ and $Q_{60}$ for white : total with colour, $3.07 ; n=3, \mathrm{P}=0.30-0.50$.

which produced only white tubers, showed, as in those formed after eye-excision, that the nuclei of their cells still contained the genes for splash-pigmented periderm (table 6). 
Tubers of the white-tuber line from eye-excision were also treated, and the five plants produced 50 white tubers and two with purple splashes. Only further experiments, however, can show whether $\mathrm{X}$-ray treatment leads to a higher rate of reversion from white to white-splashed-purple than occurs after normal vegetative reproduction.

X-ray treatment of tubers with full periderm colour (full pink Red King, $T_{39 / 1}$, and $W_{I 0 B}$ ) produced no plants with white tubers (table 5). This is in agreement with the eye-excision results (table 2) and confirms the hypothesis that the production of white tubers after eye-excision is connected with the action of gene $M$. It is also in agreement with the suggestion that most, if not all, white tubers from X-ray experiments are not due to point mutations.

From results with known chimeras (e.g. normal Red King) it would appear that the X-ray treatment kills nearly all cells at the growing points and that only occasional cells survive to produce the growing points which give rise to the new plants. This can be seen directly as most sprouts after the X-ray treatment are blind and only produce small shoots with swollen leaves and no growing points. Some of the new growing points apparently trace back to a single surviving cell. Thus the white-splashed-pink tuber obtained from $\mathrm{X}$-ray treatment of $\mathrm{Y}_{30} / 8$ (splashed purple) produced plants which had pink, not purple, patches on its stem and, when bred from, gave hybrid progenies with splashed pink tubers and none with splashed purple (table 6). As tuber periderm traces back to layer I at the growing point, as stem colour is in the subepidermal layer produced from layer II at the growing point, and as embryo-sac mother cells also trace back to layer II, these tubers had lost the gene $P$ for purple as opposed to pink colour in at least layers I and II. This is very unlikely to have happened in two adjacent cells and it is much more likely that the new growing point after X-ray treatment has been formed by a single surviving cell. A similar explanation fits the production of full pink Red King from normal Red King.

\section{PHENOTYPE VARIATIONS}

Tubers of normal Red King, i.e. the monochlamydius chimera, show a certain range in phenotypes which is apparently correlated with the proportions of the periderm which trace back to either layer I (full pigmentation) or layer II (splashed pigment). Most Red King tubers show a number of white patches, often just below the eyes, and also a patch at the heel and around the stolon attachment (fig. Ib). Occasional tubers can be found on which there are no white patches, but when grown on such tubers always produce plants which have tubers with the characteristic white patches. Other occasional tubers, see fig. 3a, may have a large area at the heel end without colour. When such a tuber is cut to make two sets, both the unpigmented heel end and the pigmented rose end produce plants which have typical Red King tubers. It thus seems probable that in 
the original tuber the unpigmented heel end was due to the periderm in that half of the tuber having developed from a cambium produced in the outer cortex which traces back to layer II at the growing point and not from a cambium formed in the epidermis which traces back to layer I.

In full pink Red King, in which both layers I and II have only the gene for fully pigmented periderm and lack $M$, the pigment restricting gene, no white patches are found on the tubers (Howard, $1959 b)$. There are, however, areas of somewhat less bright pink periderm which correspond in position to the white areas on normal Red King tubers. These are presumably areas where the periderm has been formed from a cambium originating in the outer cortex and not in the epidermis.

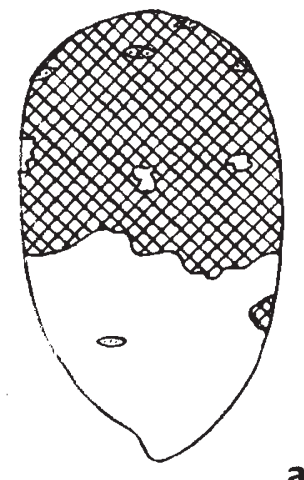

a

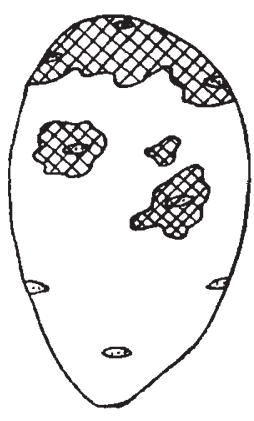

b

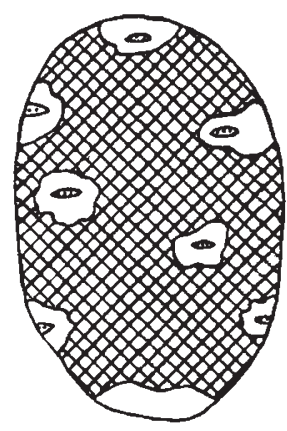

c

FIG. 3.-Tuber phenotypes (areas of pigmented periderm cross-hatched).

(a) Tuber of normal Red King (periclinal chimera) with a white heel (stolon attachment) end.

(b) Typical white-splashed-pigment tuber.

(c) "Spectacled "type tuber of the variety Gladstone which normally has white-splashedpink tubers.

There is, in many varieties which have tubers of the white-splashedpigment type, a wide range in tuber phenotypes. This range is almost certainly not correlated with whether the periderm originated from cambia formed either in the epidermis or in the outer cortex (see full pink Red King, above), and it would appear to be due to differences in the time at which the pigment-restricting gene, $M$, acts. If the gene is effective during the whole time of tuber growth, then an almost white tuber is produced, whereas, if it acts for only a short time, almost fully coloured tubers may be found. The typical phenotype produced by the gene is shown in fig. $3^{b}$. There are large pigmented patches at the rose (apical) end but the heel (stolon attachment) end has no pigmented areas. Dividing such a tuber into rose-end and heel-end sets results in plants which both bear tubers of the typical phenotype.

White tubers, without any pigmented splashes, are fairly common in many varieties with white-splashed-pigment tubers. They were 
not, however, found in $\mathrm{Y}_{30} / 8$ which was specially selected for the eye-excision experiments because of the constancy of tubers with well-marked splashes. Plants grown from these white tubers invariably bear tubers which are white-splashed-pigment. Another phenotypic variation is the "spectacled" type, fig. $3 c$, in which the tuber is full coloured except for white areas around the eyes. Plants from such tubers again produce typical white-splashed-pigment tubers. It should be noted, however, that there are clones of Solanum tuberosum subsp. andigena which always have spectacle-type tubers and that this genetic type is also known in the cultivated, diploid potato, $S$. phureja (Dodds and Long, 1956).

\section{DISCUSSION}

(i) Action of the gene $\mathrm{E}$

In the cultivated tetraploid potato, $S$. tuberosum, tuber skin colour is determined by a basic gene, $D$; a gene, $E$, for periderm pigmentation; and a gene, $R$, for outer cortical pigmentation (Lunden, I 937). Thus $E D$ plants have tubers with pigmented periderm and no pigment in the outer cortex and other tissues of the tuber. The different response to the genes $E D$ of the periderm cells from those of the other tuber tissues is apparently due to special conditions inside a periderm cell. Thus, when cortex or vascular system cells are made by eyeexcision to dedifferentiate to produce meristematic cells, the new periderm cells, which are eventually produced by the plants originating as adventitious buds, are able to produce pigment.

\section{(ii) Action of the gene $M$}

The action of the pigment-restricting gene $M$, at least when it is in close proximity to the gene $E$, is to prevent pigment formation in certain of the periderm cells so that white-splashed-pigment tubers are produced. Thus we are concerned here with a differential reaction of cells in the same tissue and not in different tissues as discussed above. This differentiation of cells, due to the action of the gene $M$, into those capable of producing pigmented periderm and those not capable, apparently also takes place in the cells of the inner tissues. Thus, when cortex and vascular system cells of whitesplashed-pigment tubers are made by eye-excision to form adventitious buds, the plants formed by some of the adventitious buds have white tubers without any pigmented splashes. The subsequent behaviour of clonal lines from these white tubers suggests that the stopping of pigment formation is nearly permanent under conditions of mitotic divisions. It does not persist, however, when the cells and their nuclei take part in meiosis and sexual reproduction.

$A$ priori the change in a cell, due to the gene $M$, from capable to not capable of producing pigment could be due to a change either in the cytoplasm or in the chromosome in which the genes $E$ and $M$ 
occur. Because the crosses of white-tubered plants obtained by eyeexcision or X-ray treatment from white-splashed-pink clones were all made with these plants as female parents and because they gave similar segregations to those obtained from the white-splashed-pigment parents, there is no evidence for a change in the cytoplasm. This does not mean, however, that it must be a change in the chromosome carrying the genes $E$ and $M$, and there does not seem to be any experiment with these potatoes which could determine whether the change is in the cytoplasm or in the nucleus.

\section{(iii) X-ray experiments}

The results of the X-ray experiments are important in two ways. First they give ample confirmation to the conclusion drawn from the eye-excision experiments that it is only $E M$ and not $E m$ genotypes from which plants with white tubers can be obtained. Secondly they show that the action of the gene $M$ takes place close to the growing point and not in cells far away from it and certainly not only in cells of the internal tissues as was suggested by Howard (1959a). This conclusion can be drawn because the shoots which produce plants after X-ray treatment arise from small buds in the eyes, and not as in the eye-excision experiments from adventitious buds formed on calluses produced by the inner tissues.

\section{SUMMARY}

I. Eye-excision experiments with tubers of potato clones of the type white-splashed-pigment periderm produce some plants which have white tubers. These white tubers give rise to plants which themselves have white tubers.

2. Breeding from plants grown from the white tubers shows that the plants still have the genes for white-splashed-pigment periderm.

3. X-ray treatment of white-splashed-pigment tubers also produces some plants which have white tubers. Plants grown from these white tubers show the same behaviour as plants grown from the white tubers from eye-excision experiments.

4. Both eye-excision experiments and X-ray treatments of tubers with full coloured periderm produce no plants with white tubers. It is thus only the genotype $D E M$, and not $D E$, from which white tubers can be obtained by eye-excision or X-ray treatment.

5. Variations in phenotype produced by the pigment-restricting gene $M$ are discussed.

6. It is not possible to decide whether the periderm cells of the $D E M$ genotype which do not produce pigment differ either in the cytoplasm or in the chromosome carrying $E M$ from those producing pigment.

Acknowledgment.-My thanks arc due to $\mathrm{Mr}$ E. A. King of the Department of Radiotherapeutics, University of Cambridgc, for making the X-ray treatments. 


\section{REFERENCES}

AsSEYeVA, T. 1931. Bud mutations in the potato. Bull. appl. Bot., Leningrad, 27 , $135^{-21} 7$.

CATCHESIDE, D. G. 1959. Segregation in tetraploid potatoes. Heredity, 13, 403-407. DODDS, K. S., AND LONG, D. H. 1956. The inheritance of colour in diploid potatoes. II. A three factor linkage group. J. Genet., 54, 27-41.

HOWARD, H. W. 1958. Transformation of a monochlamydius into a dichlamydius chimæra by X-ray treatment. Nature, Lond., 182, 1620.

HOWARD, H. W. 1959a. Differentiation in the potato tuber. Heredity, 13, 417 (Abstract).

HOWARD, H. W. 1959b. Experiments with a potato periclinal chimera. Genetica, 30, $278-291$.

LUNDEN, A. P. 1937. Arvelighetsundersokelser i potet. Meld. Norg. LandHoisk., $20,1-156$. 